\title{
Treatment of Parkinson's disease in the advanced stage
}

\author{
C. Ossig $\cdot$ H. Reichmann
}

Received: 18 September 2012/ Accepted: 4 March 2013/Published online: 10 March 2013

(C) The Author(s) 2013. This article is published with open access at Springerlink.com

\begin{abstract}
Levodopa/Carbidopa, respectively, Levodopa/ Benserazide is the most effective treatment for Parkinson's disease and during the progress of the disease, patients will inevitably need to be treated with it. Nonetheless, after a certain time period most of the patients experience side effects. Mainly disturbing are motor and non-motor fluctuations and dyskinesia. Numerous options from changing the medication regimen, to continuos dopaminergic drug delivery via apomorphine or Duodopa pumps and stereotactical interventions are available. The physician's responsibility is to choose the right therapeutic procedure for each timepoint of the patient's disease. In this review, we provide an up to date overview of the available strategies.
\end{abstract}

Keywords Dyskinesia - Motor fluctuations · Advanced Parkinson's disease $\cdot$ Levodopa

\section{Introduction}

As one of the main pillars in the therapy of Parkinson's disease (PD), Levodopa/Carbidopa (LC), respectively, Levodopa/Benserazide (LB) is the mainstay in treatment, with the highest antiparkinsonian efficacy. LC/LB increases the survival rate and the quality of life and will have to be added to any treatment regimen in the longrun (Olanow et al. 2004). Side effects of LC/LB treatment comprise nausea, vomiting, orthostatic hypotension, cognitive impairment, psychosis and obsessive compulsive

C. Ossig $(\bowtie) \cdot$ H. Reichmann

Department of Neurology, Dresden University of Technology,

Dresden, Germany

e-mail: christiana.ossig@uniklinikum-dresden.de disorders (OCD). In the ELLDOPA study, Fahn (2005) was able to show the significant improvement of Parkinson's patients, measured on the Unified Parkinson Disease Rating Scale (UPDRS), depending on the dose of LC/LB therapy. However, depending on the daily dose of LC/LB, the onset of motor fluctuations and dyskinesia is often in as little time as 5-6 months to 2 years (Stocchi and Rabey 2011; Fahn 2005). Due to this disease development and Levodopa-induced side effects (LID), therapeutic regimens have to be adjusted and different strategies have to be considered.

\section{Fluctuations and dyskinesia}

The underlying pathophysiology of Levodopa-induced fluctuations and dyskinesia is unknown, but the overall opinion is that it might be due to a discontinuous stimulation of the striatal dopamine receptors as opposed to the continuous supply of dopamine in the healthy individual (Olanow et al. 2006). Especially younger patients, with a PD onset before the age of 50, with high intake of LC/LB for an increased duration of time are at risk for developing motor fluctuations and dyskinesia (Kostic et al. 1991). In addition, female sex seems to be a risk factor (Schrag and Quinn 2000). Motor fluctuations can present as "end-of-dose" or "wearing-off" phenomenon, sometimes with even unpredictable "off" episodes. In addition, a delayed "on" or no "on" response after medication intake may occur. Non-motor fluctuations can present not only as severe anxiety, restlessness and mood swings but also as physical symptoms like urinary disorder, hyperhidrosis, fatigue and sleep disorders (Barone et al. 2009; Antonini et al. 2008a). Dyskinesias may appear at the highest level of Levodopa effectiveness as "peak dose" dyskinesia, but may also present as biphasic dyskinesia, before and after LC/LB dose interval. 
Once fluctuations and dyskinesia emerge, the pharmacodynamic response changes, resulting in a narrowing of the "therapeutic window" and a specific levodopa threshold is needed for a sufficient clinical response (Mouradian et al. 1989). Motor fluctuations can primarily be kept under control by increasing the daily dose of LC/LB, and hence, increase "on" time, by risking the occurrence of dyskinesia or applying more frequently smaller dosages of LC/LB, consequently reduce dyskinesia but venture to increase the "off" time. Shortening the intervals between the LC/LB intakes may, however, reduce the compliance of patients (Grosset et al. 2005). Before changing a current medical schedule, the patient should be reminded of the reduced bioavailability of $\mathrm{LC} / \mathrm{LB}$, when a protein-rich meal is consumed.

\section{Non-invasive therapeutical options}

Levodopa/Carbidopa or Levodopa/Benserazide and MAO-B Inhibitors

Dopamine concentrations can be increased by blockage of the monoamine oxidase-B (MAO-B) leading to a reduced metabolism of dopamine in the brain. Selegiline (SE) was the first MAO-B inhibitor approved by the FDA in 1996. Daily treatment with $10 \mathrm{mg}$ SE leads to an improvement of 3 points on the total UPDRS and 1.7 points on the motor subscale of the UPDRS after 3 months (Parkinson Study Group 1993). Since the metabolites of SE, metamphetamine and amphetamine, are capable to inhibit the peripheral monoamine oxidase-A (MAO-A) and therefore hold a potential risk of dietary tyramine-provoked hypertensive crisis, high dosages of SE should be avoided. Adding $0.5-1 \mathrm{mg}$ rasagiline (RA) to the LC/LB therapy results significantly in a reduced "off" time and an increase in "on" time as shown in the PRESTO (Parkinson Study Group 2005) and LARGO study (Stocchi and Rabey 2011; Rascol et al. 2005). The excellent side effect profile of RA has been confirmed in the ADAGIO trial, which showed no significant differences in adverse events between placebo treated patients and study participants receiving 1-2 mg of RA (Olanow et al. 2009). Data from preclinical studies have suggested that MAO-B inhibitors may have neuroprotective properties (Heikkila et al. 1984). Considering clinical studies, only the open-label extension of the TEMPO study demonstrated that early RA treatment provided a long-term clinical benefit, suggesting at least some rationale for a disease-modifying effect of RA (Hauser et al. 2009). However, the MAO-B inhibitors may reinforce the appearance of dyskinesia and lead to dopaminergic side effects.
Levodopa/Carbidopa or Levodopa/Benserazide and COMT inhibitors

Levodopa is partly metabolised by the catechol-O-methyl transferase (COMT). Inhibitors of COMT increase the elimination half-life of Levodopa and boost the effect of each tablet by approximately $30 \%$. Two selective inhibitors are commonly used: Entacapone (a peripheral COMT inhibitor) and Tolcapone (a peripheral and central acting COMT inhibitor). Tolcapone possesses the ability of greater COMT inhibition (Deane et al. 2004) but since sporadic cases of hepatotoxicity have occurred, regular blood test is mandatory. Besides this distinctive feature, side effects resemble LC/LB. Adjunction of a COMT inhibitor to the LC/LB treatment leads to an increase in "on" time, a reduction in "off" time and an improvement of motor scores in the fluctuating PD patient (Parkinson Study group 1997). However, the adjunct of Entacapone to LC/LB failed to delay the time of onset or reduce the frequency of dyskinesia as shown in the STRIDE-PD study (Stocchi et al. 2010). In this double blind trial, every $3.5 \mathrm{~h}$ LC/LB or LC/LB plus entacapone (LE) was administered. Patients who received LE had an increased risk in developing dyskinesia compared to the control group. Dyskinesia under LE treatment were even more common when patients were younger than 65 years of age, of male sex, with a body weight $>75 \mathrm{~kg}$, with a disease duration less then 2 years and an additional treatment with a MAO-B inhibitor or dopamine agonist (Stocchi et al. 2010).

\section{Levodopa and dopamine agonists}

The commonly oral used dopamine agonists (DA) are ropinirole, piribedil and pramipexole. Rotigotine is applied transdermally. DA is often applied as an initial treatment in PD due to their low potential to develop dyskinesia (Rascol et al. 2000). However, the majority of patients receiving DA will also need LC/LB after 2-5 years (Holloway et al. 2004). Being initially developed as an add-on therapy to LC/LB, several studies have shown a significant reduction of "off" time of about 1.1-1.5 h per day (Olanow et al. 1994; Pinter et al. 1999). Nowadays, mainly 24 h prolonged release formulations of DA are in use and have shown significant reduction of "off" time (Pahwa et al. 2007). Side effects resemble LC/LB treatment; however, increased daytime sleepiness and skin irritations in the transdermally applied form may occur. Recent reports have also linked DA therapy to pathologic gambling, eating disorders and hypersexuality (Stocchi 2005; Antonini and Cilia 2009). Interestingly, the use of ropinirole as initial therapy of early PD showed a reduced incidence of dyskinesia for up to 5 years, regardless of supplemental 
LC/LB therapy (Rascol et al. 2000). Recently, Watts et al. (2010) investigated that the addition of prolonged release ropinirole to LC/LB therapy delays the occurrence of dyskinesia. In addition, non-motor fluctuations can improve from add-on therapy of DA to LC/LB. The RECOVER study showed that adjunction of $24 \mathrm{~h}$ transdermal rotigotine treatment is associated with significant benefits in the management of early morning motor impairment, nocturnal sleep disturbances and non-motor daytime symptoms such as fatigue and mood changes (Trenkwalder et al. 2011).

Therapeutic algorithm regarding non-invasive therapeutical options

Figure 1 offers an overview how treatment should be adjusted according to the occurrence of common subtypes of dyskinesia and motor fluctuations.

\section{Invasive therapeutical options}

If symptoms cannot sufficiently be controlled by orally applicated medication, invasive therapeutical options must be considered. Continuous dopaminergic drug delivery (CDD) can be achieved by continuous subcutaneous apomorphine infusions (CAI) or duodenal infusions of Levodopa (Duodopa) via portable minipumps (Hilker et al. 2011). Constant dopaminergic stimulation of the receptors is associated with a reduced risk of motor fluctuations compared to treatment with intermittent dosages of standard oral LC/LB (Obeso et al. 1994). In healthy individuals, dopaminergic neurons in the substantia nigra fire at a constant frequency (Grace and Bunney 1984) and striatal dopamine levels are not subject to temporary fluctuations (Venton et al. 2003).

\section{Apomorphine}

Apomorphine is a D1/D2 receptor DA with a short half-life of nearly $45 \mathrm{~min}$ and is, therefore, extremely effective considering time from injection to onset of clinical effects and mean duration of symptom relief (Neef and van Laar 1999). Apomorphine injections via pen administration are reasonable for a rapid relieve of a sudden "off" fluctuation during the daytime and nighttime and to conquer end-ofdose biphasic dyskinesia (Frankel et al. 1990). Continuous infusion can be enabled by an apomorphine pump. Via this modified insulin pump, a programmed infusion rate is dispensed in most cases using a 12-16 h regimen. If needed, the pump can administer apomorphine for $24 \mathrm{~h}$ and does not have to be discontinued overnight. This has resulted in a reduced nocturnal off-time (Reuter et al. 1999). Furthermore, a specifically defined bolus application can be given whenever needed. Treatment should be started under medical supervision and a premedication with domperidone should be utilised to reduce side effects (Bowron 2004). For analysis of circulating antibodies against erythrocytes, a
Fig. 1 Therapeutic algorithm for orally applicated medication according to symptoms


Adaption:
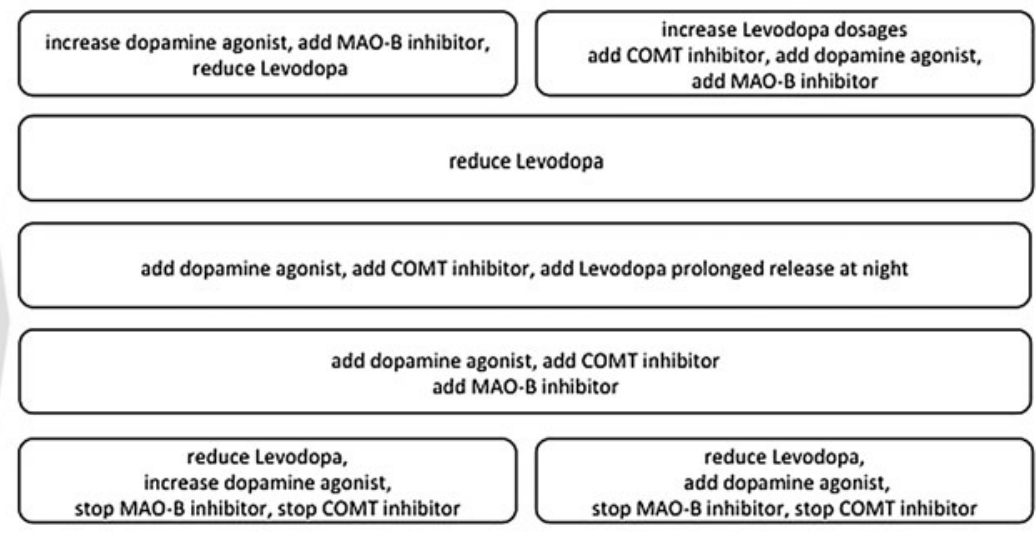

increase Levodopa and split up in smaller dosages, add COMT inhibitor 
Coombs test should be performed beforehand. One of the main side effects are skin reactions, located at the injection side resulting in a formation of small nodules (Deleu et al. 2004). Other side effects include increased daytime sleepiness, nausea, dizziness, renal impairment and orthostatic hypotension (Manson et al. 2001; Stocchi et al. 2001). Neuropsychiatric changes like hallucinations and psychosis are rare but can be observed with high dosages of apomorphine. CAI may provide a significant improvement of mood (Morgante et al. 2004).

\section{Duodopa}

Duodopa is a combination of Levodopa $(20 \mathrm{mg} / \mathrm{ml})$ and Carbidopa $(5 \mathrm{mg} / \mathrm{ml})$ applied in form of a gel into the duodenum. Preceding the permanent therapy, a test application period of Duodopa via a nasoduodenal catheter system is generally used. If this is well tolerated by the patient and symptoms improve, a percutaneous, endoscopic gastrostomy (PEG) is performed and Duodopa is delivered via a portable pump and a duodenal catheter. If the retention period is $24 \mathrm{~h}$, Duodopa is given as a monotherapy. If the Duodopa treatment is subject to a $16 \mathrm{~h}$ regimen, a prolonged release Levodopa tablet is often administered before bedtime. A number of studies have shown a significant reduction of time in "off" and a significant increase of time in "on", as well as a reduction of dyskinesia (Antonini et al. 2008b; Eggert et al. 2008). In addition, an improvement of the non-motor symptoms including sleep and pain, gastrointestinal, urological and cognitive issues was stated (Honig et al. 2009). Adverse events are mainly due to technical reasons like dislocation, obstruction and breakage of the duodenal catheter. In very rare cases, PEG related side effects are monitored. These include peritonitis and local stoma inflammation.

Deep brain stimulation

The use of continuous high frequency "deep brain" stimulation (DBS) was established in the early 90s and is widely used with great benefit (Benabid et al. 1994). The implanted electrodes can be adjusted by changing the voltage, the pulse width and the frequency to improve symptoms and/or reduce potential side effects. In PD patients, the stimulation of either the subthalamic nuclei (STN) or the internal global pallidum (GPi) is mainly performed. The duration of benefit following GPi DBS is, however, variable. After STN DBS, an improvement in all main cardinal features of PD as well as a reduction of the mean severity and duration of dyskinesia has been documented in several studies (Limousin et al. 1998; Krack et al. 2003; Weaver et al. 2012). The best predictor for a favourable result is a good Levodopa response (Charles et al. 2002). Ideal candidates for STN DBS are patients below the age of 70 years, with motor fluctuations and dyskinesia or tremor and without cognitive or behavioural deficits. Side effects of the DBS include intracranial haemorrhage and infarction. Postoperational complications
Fig. 2 Invasive therapeutical options for advanced Parkinson's disease treatment
Patients with dyskinesia and motor fluctuations which can not longer be controlled by orally applicated medication

\begin{tabular}{|c|c|c|c|}
\hline & Apomorphine pump & Duodopa pump & Deep brain stimulation \\
\hline Age & $\begin{array}{l}\checkmark \text { no age limitation, cave: } \\
\text { hallucinations and } \\
\text { psychosis in patients } \\
>70 \text { years }\end{array}$ & $\checkmark$ no age limitation & $\begin{array}{l}\checkmark \text { patients should not be } \\
\text { older than } 70 \text { years }\end{array}$ \\
\hline $\begin{array}{l}\text { Existing } \\
\text { psychiatric } \\
\text { diseases }\end{array}$ & $\begin{array}{l}\checkmark \text { no limitation, however } \\
\text { carefully monitoring is } \\
\text { advisable }\end{array}$ & $\checkmark$ no limitation & $\begin{array}{l}\checkmark \text { no psychiatric medical } \\
\text { history }\end{array}$ \\
\hline $\begin{array}{l}\text { Cognitive } \\
\text { Impairment }\end{array}$ & $\begin{array}{l}\checkmark \text { no or mild cognitive } \\
\text { impairment }\end{array}$ & $\begin{array}{l}\checkmark \text { no limitation regarding } \\
\text { cognitive impairment }\end{array}$ & $\begin{array}{l}\checkmark \text { no cognitive } \\
\text { impairment (MMST } \\
>24 \text { ) }\end{array}$ \\
\hline $\begin{array}{l}\text { Follow-up } \\
\text { treatment }\end{array}$ & $\begin{array}{l}\checkmark \text { technical adjustments } \\
\text { by patients or caregiver } \\
\text { possible, regular check } \\
\text { by physician }\end{array}$ & $\begin{array}{l}\checkmark \text { technical adjustments } \\
\text { by patients or caregiver } \\
\text { possible, regular check } \\
\text { by physician }\end{array}$ & $\begin{array}{l}\checkmark \text { technical adjustments } \\
\text { only by physician }\end{array}$ \\
\hline
\end{tabular}


involve confusion, pneumonia, infection and in older patients pulmonary embolism (Voges et al. 2007). Lead breakage, extension wire failure, impulse generator malfunctions-generally referred to as hardware-related complications-typically appear within the first 3 months after operation (Baizabal Carvallo et al. 2012; Lyons et al. 2004). Stimulation-induced side effects include dysarthria, hypophonia, dizziness, eyelid opening apraxia and oculomotor deficits (Deuschl et al. 2006). Neuropsychiatric changes like post surgery depression and especially a 13-fold increased risk for suicide within the first year after STN DBS have been the cause for concern (Voon et al. 2008). A recent study did not find a difference in functional health measured by time spent in "on" and "off", behavioural side effects, cognition and mood in patients who received GPi DBS or STN DBS (Odekerken et al. 2013).

Conclusion regarding invasive therapeutical options

The indication for any invasive therapeutical optioncontinuous infusion of apomorphine or Duodopa via pumps or DBS via stereotactical operation-should be carefully placed (compare Fig. 2). As apomorphine pumps are small and of lower weight compared to Duodopa pumps, it need less technical requirements and are generally easy to apply and completely reversible. CAI is often used as an interim solution before DBS. The side effects can be generally controlled well; however, a continuation of the orally administered medication is almost always necessary. Until today comparative studies with CAI and Duodopa have not been accomplished. However, the effect of Duodopa on "off" time is distinct. DBS shows great benefit in controlling PD symptomatology and offers more independence for patients than treatment with pumps; however, the indication for undergoing stereotactical operation must be strictly adhered to receive a satisfying outcome. For a good clinical outcome with any invasive therapeutical option, a high patient motivation is needed, a necessary detailed patient education, regular follow-up visits in a specialised setting and a stable support of the patient by his environment.

Conflict of interest The authors declare that they have no conflict of interest.

Open Access This article is distributed under the terms of the Creative Commons Attribution License which permits any use, distribution, and reproduction in any medium, provided the original author(s) and the source are credited.

\section{References}

Antonini A, Cilia R (2009) Behavioural adverse effects of dopaminergic treatments in Parkinson's disease: incidence, neurobiological basis, management and prevention. Drug Saf 32(6):475-488. doi:10.2165/00002018-200932060-00004

Antonini A, Colosimo C, Marconi R, Morgante L, Barone P (2008a) The PRIAMO study: background, methods and recruitment. Neurol Sci 29(2):61-65. doi:10.1007/s10072-008-0863-Z

Antonini A, Mancini F, Canesi M, Zangaglia R, Isaias IU, Manfredi L, Pacchetti C, Zibetti M, Natuzzi F, Lopiano L, Nappi G, Pezzoli G (2008b) Duodenal levodopa infusion improves quality of life in advanced Parkinson's disease. Neurodegener Dis 5(3-4):244-246. doi:10.1159/000113714

Baizabal Carvallo JF, Mostile G, Almaguer M, Davidson A, Simpson R, Jankovic J (2012) Deep brain stimulation hardware complications in patients with movement disorders: risk factors and clinical correlations. Stereotact Funct Neurosurg 90(5):300-306. doi: $10.1159 / 000338222$

Barone P, Antonini A, Colosimo C, Marconi R, Morgante L, Avarello TP, Bottacchi E, Cannas A, Ceravolo G, Ceravolo R, Cicarelli G, Gaglio RM, Giglia RM, Iemolo F, Manfredi M, Meco G, Nicoletti A, Pederzoli M, Petrone A, Pisani A, Pontieri FE, Quatrale R, Ramat S, Scala R, Volpe G, Zappulla S, Bentivoglio AR, Stocchi F, Trianni G, Dotto PD (2009) The PRIAMO study: a multicenter assessment of nonmotor symptoms and their impact on quality of life in Parkinson's disease. Mov Disord 24(11):1641-1649. doi:10.1002/mds.22643

Benabid AL, Pollak P, Gross C, Hoffmann D, Benazzouz A, Gao DM, Laurent A, Gentil M, Perret J (1994) Acute and long-term effects of subthalamic nucleus stimulation in Parkinson's disease. Stereotact Funct Neurosurg 62(1-4):76-84

Bowron A (2004) Practical considerations in the use of apomorphine injectable. Neurology 62(6 Suppl 4):S32-S36

Charles PD, Van Blercom N, Krack P, Lee SL, Xie J, Besson G, Benabid AL, Pollak P (2002) Predictors of effective bilateral subthalamic nucleus stimulation for PD. Neurology 59(6):932934

Deane KH, Spieker S, Clarke CE (2004) Catechol-O-methyltransferase inhibitors for levodopa-induced complications in Parkinson's disease. Cochrane Database Syst Rev 4:CD004554. doi: 10.1002/14651858.CD004554.pub2

Deleu D, Hanssens Y, Northway MG (2004) Subcutaneous apomorphine : an evidence-based review of its use in Parkinson's disease. Drugs Aging 21(11):687-709

Deuschl G, Herzog J, Kleiner-Fisman G, Kubu C, Lozano AM, Lyons KE, Rodriguez-Oroz MC, Tamma F, Troster AI, Vitek JL, Volkmann J, Voon V (2006) Deep brain stimulation: postoperative issues. Mov Disord 21(Suppl 14):S219-S237. doi:10.1002/ mds. 20957

Eggert K, Schrader C, Hahn M, Stamelou M, Russmann A, Dengler R, Oertel W, Odin P (2008) Continuous jejunal levodopa infusion in patients with advanced parkinson disease: practical aspects and outcome of motor and non-motor complications. Clin Neuropharmacol 31(3):151-166. doi:10.1097/wnf.0b013 e31814b113e

Fahn S (2005) Does levodopa slow or hasten the rate of progression of Parkinson's disease? J Neurol 252(Suppl 4):IV37-IV42. doi: 10.1007/s00415-005-4008-5

Frankel JP, Lees AJ, Kempster PA, Stern GM (1990) Subcutaneous apomorphine in the treatment of Parkinson's disease. J Neurol Neurosurg Psychiatry 53(2):96-101

Grace AA, Bunney BS (1984) The control of firing pattern in nigral dopamine neurons: single spike firing. J Neurosci 4(11):28662876

Grosset KA, Reid JL, Grosset DG (2005) Medicine-taking behavior: implications of suboptimal compliance in Parkinson's disease. Mov Disord 20(11):1397-1404. doi:10.1002/mds.20525

Hauser RA, Lew MF, Hurtig HI, Ondo WG, Wojcieszek J, FitzerAttas CJ (2009) Long-term outcome of early versus delayed 
rasagiline treatment in early Parkinson's disease. Mov Disord 24(4):564-573. doi:10.1002/mds.22402

Heikkila RE, Manzino L, Cabbat FS, Duvoisin RC (1984) Protection against the dopaminergic neurotoxicity of 1-methyl-4-phenyl1,2,5,6-tetrahydropyridine by monoamine oxidase inhibitors. Nature 311(5985):467-469

Hilker R, Antonini A, Odin P (2011) What is the best treatment for fluctuating Parkinson's disease: continuous drug delivery or deep brain stimulation of the subthalamic nucleus? J Neural Transm 118(6):907-914. doi:10.1007/s00702-010-0555-8

Holloway RG, Shoulson I, Fahn S, Kieburtz K, Lang A, Marek K, McDermott M, Seibyl J, Weiner W, Musch B, Kamp C, Welsh M, Shinaman A, Pahwa R, Barclay L, Hubble J, LeWitt P, Miyasaki J, Suchowersky O, Stacy M, Russell DS, Ford B, Hammerstad J, Riley D, Standaert D, Wooten F, Factor S, Jankovic J, Atassi F, Kurlan R, Panisset M, Rajput A, Rodnitzky R, Shults C, Petsinger G, Waters C, Pfeiffer R, Biglan K, Borchert L, Montgomery A, Sutherland L, Weeks C, DeAngelis M, Sime E, Wood S, Pantella C, Harrigan M, Fussell B, Dillon S, Alexander-Brown B, Rainey P, Tennis M, Rost-Ruffner E, Brown D, Evans S, Berry D, Hall J, Shirley T, Dobson J, Fontaine D, Pfeiffer B, Brocht A, Bennett S, Daigneault S, Hodgeman K, O'Connell C, Ross T, Richard K, Watts A (2004) Pramipexole vs levodopa as initial treatment for Parkinson disease: a 4-year randomized controlled trial. Arch Neurol 61(7):1044-1053. doi:10.1001/archneur.61.7.1044

Honig H, Antonini A, Martinez-Martin P, Forgacs I, Faye GC, Fox T, Fox K, Mancini F, Canesi M, Odin P, Chaudhuri KR (2009) Intrajejunal levodopa infusion in Parkinson's disease: a pilot multicenter study of effects on nonmotor symptoms and quality of life. Mov Disord 24(10):1468-1474. doi:10.1002/mds.22596

Kostic V, Przedborski S, Flaster E, Sternic N (1991) Early development of levodopa-induced dyskinesias and response fluctuations in young-onset Parkinson's disease. Neurology 41(2(Pt 1)): 202-205

Krack P, Batir A, Van Blercom N, Chabardes S, Fraix V, Ardouin C, Koudsie A, Limousin PD, Benazzouz A, LeBas JF, Benabid AL, Pollak P (2003) Five-year follow-up of bilateral stimulation of the subthalamic nucleus in advanced Parkinson's disease. N Engl J Med 349(20):1925-1934. doi:10.1056/NEJMoa035275

Limousin P, Krack P, Pollak P, Benazzouz A, Ardouin C, Hoffmann D, Benabid AL (1998) Electrical stimulation of the subthalamic nucleus in advanced Parkinson's disease. N Engl J Med 339(16):1105-1111. doi:10.1056/NEJM199810153391603

Lyons KE, Wilkinson SB, Overman J, Pahwa R (2004) Surgical and hardware complications of subthalamic stimulation: a series of 160 procedures. Neurology 63(4):612-616

Manson AJ, Hanagasi H, Turner K, Patsalos PN, Carey P, Ratnaraj N, Lees AJ (2001) Intravenous apomorphine therapy in Parkinson's disease: clinical and pharmacokinetic observations. Brain 124(Pt 2):331-340

Morgante L, Basile G, Epifanio A, Spina E, Antonini A, Stocchi F, Di Rosa E, Martino G, Marconi R, La Spina P, Nicita-Mauro V, Di Rosa AE (2004) Continuous apomorphine infusion (CAI) and neuropsychiatric disorders in patients with advanced Parkinson's disease: a follow-up of two years. Arch Gerontol Geriatr Suppl 9:291-296. doi:10.1016/j.archger.2004. 04.039

Mouradian MM, Heuser IJ, Baronti F, Fabbrini G, Juncos JL, Chase TN (1989) Pathogenesis of dyskinesias in Parkinson's disease. Ann Neurol 25(5):523-526. doi:10.1002/ana.410250521

Neef C, van Laar T (1999) Pharmacokinetic-pharmacodynamic relationships of apomorphine in patients with Parkinson's disease. Clin Pharmacokinet 37(3):257-271

Obeso JA, Grandas F, Herrero MT, Horowski R (1994) The role of pulsatile versus continuous dopamine receptor stimulation for functional recovery in Parkinson's disease. Eur J Neurosci 6(6):889-897

Odekerken VJ, van Laar T, Staal MJ, Mosch A, Hoffmann CF, Nijssen PC, Beute GN, van Vugt JP, Lenders MW, Contarino MF, Mink MS, Bour LJ, van den Munckhof P, Schmand BA, de Haan RJ, Schuurman PR, de Bie RM (2013) Subthalamic nucleus versus globus pallidus bilateral deep brain stimulation for advanced Parkinson's disease (NSTAPS study): a randomised controlled trial. Lancet Neurol 12(1):37-44. doi:10.1016/ S1474-4422(12)70264-8

Olanow CW, Fahn S, Muenter M, Klawans H, Hurtig H, Stern M, Shoulson I, Kurlan R, Grimes JD, Jankovic J et al (1994) A multicenter double-blind placebo-controlled trial of pergolide as an adjunct to Sinemet in Parkinson's disease. Mov Disord 9(1):40-47. doi:10.1002/mds.870090107

Olanow CW, Agid Y, Mizuno Y, Albanese A, Bonuccelli U, Damier P, De Yebenes J, Gershanik O, Guttman M, Grandas F, Hallett M, Hornykiewicz O, Jenner P, Katzenschlager R, Langston WJ, LeWitt P, Melamed E, Mena MA, Michel PP, Mytilineou C, Obeso JA, Poewe W, Quinn N, Raisman-Vozari R, Rajput AH, Rascol O, Sampaio C, Stocchi F (2004) Levodopa in the treatment of Parkinson's disease: current controversies. Mov Disord 19(9):997-1005. doi:10.1002/mds.20243

Olanow CW, Obeso JA, Stocchi F (2006) Continuous dopaminereceptor treatment of Parkinson's disease: scientific rationale and clinical implications. Lancet Neurol 5(8):677-687. doi: 10.1016/S1474-4422(06)70521-X

Olanow CW, Rascol O, Hauser R, Feigin PD, Jankovic J, Lang A, Langston W, Melamed E, Poewe W, Stocchi F, Tolosa E (2009) A double-blind, delayed-start trial of rasagiline in Parkinson's disease. N Engl J Med 361(13):1268-1278. doi:10.1056/ NEJMoa0809335

Pahwa R, Stacy MA, Factor SA, Lyons KE, Stocchi F, Hersh BP, Elmer LW, Truong DD, Earl NL (2007) Ropinirole 24-hour prolonged release: randomized, controlled study in advanced Parkinson disease. Neurology 68(14):1108-1115. doi:10.1212/ 01.wnl.0000258660.74391.c1

Parkinson Study Group (1993) Effects of tocopherol and deprenyl on the progression of disability in early Parkinson's disease. N Engl J Med 328(3):176-183

Parkinson Study Group (1997) Entacapone improves motor fluctuations in levodopa-treated Parkinson's disease patients. Ann Neurol 42(5):747-755. doi:10.1002/ana.410420511

Parkinson Study Group (2005) A randomized placebo-controlled trial of rasagiline in levodopa-treated patients with Parkinson disease and motor fluctuations: the PRESTO study. Arch Neurol 62(2):241-248

Pinter MM, Pogarell O, Oertel WH (1999) Efficacy, safety, and tolerance of the non-ergoline dopamine agonist pramipexole in the treatment of advanced Parkinson's disease: a double blind, placebo controlled, randomised, multicentre study. J Neurol Neurosurg Psychiatry 66(4):436-441

Rascol O, Brooks DJ, Korczyn AD, De Deyn PP, Clarke CE, Lang $\mathrm{AE}$ (2000) A five-year study of the incidence of dyskinesia in patients with early Parkinson's disease who were treated with ropinirole or levodopa. 056 Study Group. N Engl J Med 342(20):1484-1491. doi:10.1056/NEJM200005183422004

Rascol O, Brooks DJ, Melamed E, Oertel W, Poewe W, Stocchi F, Tolosa E (2005) Rasagiline as an adjunct to levodopa in patients with Parkinson's disease and motor fluctuations (LARGO, Lasting effect in Adjunct therapy with Rasagiline Given Once daily, study): a randomised, double-blind, parallel-group trial. Lancet 365(9463):947-954. doi:10.1016/S0140-6736(05)71083-7

Reuter I, Ellis CM, Ray Chaudhuri K (1999) Nocturnal subcutaneous apomorphine infusion in Parkinson's disease and restless legs syndrome. Acta Neurol Scand 100(3):163-167 
Schrag A, Quinn N (2000) Dyskinesias and motor fluctuations in Parkinson's disease. a community-based study. Brain 123(Pt 11): 2297-2305

Stocchi F (2005) Pathological gambling in Parkinson's disease. Lancet Neurol 4(10):590-592. doi:10.1016/S1474-4422(05)70177-0

Stocchi F, Rabey JM (2011) Effect of rasagiline as adjunct therapy to levodopa on severity of OFF in Parkinson's disease. Eur J Neurol 18(12):1373-1378. doi:10.1111/j.1468-1331.2011.03512.x

Stocchi F, Vacca L, De Pandis MF, Barbato L, Valente M, Ruggieri S (2001) Subcutaneous continuous apomorphine infusion in fluctuating patients with Parkinson's disease: long-term results. Neurol Sci 22(1):93-94

Stocchi F, Rascol O, Kieburtz K, Poewe W, Jankovic J, Tolosa E, Barone P, Lang AE, Olanow CW (2010) Initiating levodopa/ carbidopa therapy with and without entacapone in early Parkinson disease: the STRIDE-PD study. Ann Neurol 68(1):18-27. doi:10.1002/ana.22060

Trenkwalder C, Kies B, Rudzinska M, Fine J, Nikl J, Honczarenko K, Dioszeghy P, Hill D, Anderson T, Myllyla V, Kassubek J, Steiger M, Zucconi M, Tolosa E, Poewe W, Surmann E, Whitesides J, Boroojerdi B, Chaudhuri KR (2011) Rotigotine effects on early morning motor function and sleep in Parkinson's disease: a double-blind, randomized, placebo-controlled study (RECOVER). Mov Disord 26(1):90-99. doi:10.1002/mds.23441

Venton BJ, Zhang H, Garris PA, Phillips PE, Sulzer D, Wightman RM (2003) Real-time decoding of dopamine concentration changes in the caudate-putamen during tonic and phasic firing. J Neurochem 87(5):1284-1295

Voges J, Hilker R, Botzel K, Kiening KL, Kloss M, Kupsch A, Schnitzler A, Schneider GH, Steude U, Deuschl G, Pinsker MO (2007) Thirty days complication rate following surgery performed for deep-brain-stimulation. Mov Disord 22(10): 1486-1489. doi:10.1002/mds.21481

Voon V, Krack P, Lang AE, Lozano AM, Dujardin K, Schupbach M, D'Ambrosia J, Thobois S, Tamma F, Herzog J, Speelman JD, Samanta J, Kubu C, Rossignol H, Poon YY, Saint-Cyr JA, Ardouin C, Moro E (2008) A multicentre study on suicide outcomes following subthalamic stimulation for Parkinson's disease. Brain 131(Pt 10):2720-2728. doi:10.1093/brain/awn214

Watts RL, Lyons KE, Pahwa R, Sethi K, Stern M, Hauser RA, Olanow W, Gray AM, Adams B, Earl NL (2010) Onset of dyskinesia with adjunct ropinirole prolonged-release or additional levodopa in early Parkinson's disease. Mov Disord 25(7):858-866. doi: $10.1002 / \mathrm{mds} .22890$

Weaver FM, Follett KA, Stern M, Luo P, Harris CL, Hur K, Marks WJ Jr, Rothlind J, Sagher O, Moy C, Pahwa R, Burchiel K, Hogarth P, Lai EC, Duda JE, Holloway K, Samii A, Horn S, Bronstein JM, Stoner G, Starr PA, Simpson R, Baltuch G, De Salles A, Huang GD, Reda DJ (2012) Randomized trial of deep brain stimulation for Parkinson disease: thirty-six-month outcomes. Neurology 79(1):55-65. doi:10.1212/WNL.0b013 e31825dcdc1 